\title{
Condemnation of Religious Concepts: An Examination of Chubak's "An Afternoon in Late Autumn" through Bakhtin's Theory of Grotesque Realism
}

\author{
Sayed Mohammad Anoosheh \\ Yazd University, Yazd, Iran \\ Muhammad Hussein Oroskhan \\ Shiraz University, Fars, Iran
}

\section{Introduction:}

By the advent of twentieth century, Iranian society began to come out of its traditional shell and tried to be congruent with the new changes that had already been taken place in the world. Such a metamorphosis was based on external and internal forces that drove the society out its entrenched tradition. The internal factor was the establishment of Constitutional revolution between 1905 and 1911which shook the foundation of a monarchy that had been continuing for a long time. As a result, it led to the formation of the first Iranian parliament. The external factor was that the Iranian society experienced "a century of exposure to new ideas from the outside world-from colonized India, China, and Japan, from the emancipated peasantry in Russia, and from the European age of Enlightenment" (Dabashi, 2001, 17). However, in the reign of Reza Shah (1878 -1944), modernism in Iranian context strayed from its destined path from 1925andbarely expanded to be a mere imitation of the West: "Modernism in this context meant dressing, behaving and even speaking like Europeans (Sadr, 2006, 16)". While Reza Shah's modernism only embraced superficial changes, Iranian writers systematically fostered new perspectives through their works. As such, authors started producing literary works that affirmed the traces of Western modernist doctrines. In this respect, the Iranian writers vigorously noted the tendency of society toward modernism by deliberately shunning the traditional forms and producing genuine art in both short story and poetry.

Simultaneously, both poets and short story writers followed the new perspectives of modernist doctrines. The modern poetry started by Nima Yushij's (1897- 
1960)blatantly endeavor to break the monotonous routine rules of Classical Persian poetry by publishing "Afsaneh" in 1922. Nowadays, "Afsaneh" is considered to be the first modern Persian poetry by most critics (Oroskhan, 2016, 24). After a few months, Mohammad Ali Jamalzadeh (1895-1997) introduced modern short story into Persian literature by publishing a collection of short stories entitled "Once Upon a Time" which credited him as a 'father of the modern Persian literature' (Oydin, 2016 777). From this time on, short story as a new literary genre, was warmly received by Iranian people because it "differed from the earlier genres of anecdote and tale, which focused on aristocrats, and tended, unlike the latter, to represent ordinary people" (Aliakbari, 2015, 9). This new perspective revolved around the exigencies of the common people and epitomized a more nuanced study of people from different strata of society. Indeed, the first short story writers like Sadeq Hedayat (1903-1951), Mohammad Ali Jamalzadeh and Sadegh Chubak (1916-1998) undertook the "democratization of Iranian fiction"(8). This deviation from the previously well-worn style of story writing threw aboard a new form of language similar to the language of common people. This kind of style was deliberately used in Chubak's short stories to the extent that made his works unique and known. For this purpose, he picked up his characters from "the lowest strata of society"(Ghanoonparvar, 2009) because the language used in this section of the society was more adequate to his style. That is why "Chubak was chiefly responsible for introducing a whole new repertoire of southern sensibilities to the literary lexicon of Persian fiction" (Dabashi, 2012,286).

Thus, the striking feature which distinguishes Chubak from his contemporary writers is his naturalistic style of writing. According to Mostaghel, "he presents characters caught in the struggle for existence" $(1979,228)$. To represent his characters concretely, he takes out a slice of life and describes people's appalling attempts for survival, so the reader never hears a strict moralistic voice and simply enjoys an economical, crisp prose (ibid). Reza Barahani (b. 1935) as a literary critic highly praised Chubak tendency toward the depiction of the gruesome and lurid details of people's life $(1969,560-3)$. In this regard, Chubak changed the realistic approach of life disturbed the by focusing on those parts in normal life that are often neglected. By employing a colloquial language, he sketched his characters' world with sanctified subjects. Chubak annihilating the spiritual side of his subjects by recruiting the lower people's suffering into his service of writing. Thus, his method of writing can be studied through the theory of grotesque realism since it "reflects cultural shocks and shifting traditions, offering new ways of experiencing a world that is no longer quite familiar" (Gniadek, 2005, 24). In the same light, grotesque realism which was cited by Mikhail Bakhtin (1895-1975) in his masterpiece Rabelais and His World can be used to better fully illustrate Chubak's style of writing. For this purpose, one of Chubak's short stories entitled 
"An Afternoon in Late Autumn" has been taken to be thoroughly investigated with respect to Bakhtin's theory of grotesque realism.

\section{Discussion}

\subsection{Review of Literature}

The notion of carnival in popular culture has been interpreted in different ways. Such interpretations paved the way to various perspectives out of the physical act of carnival. Terry Castle in his monumental book, Masquerade and civilization, The carnivalesque in eighteenth Century English culture and fiction, refers to a form of carnival known as Public Masquerade held in urban areas of London. The ceremony is attended by thousands of people from all sections of society who disguise themselves in fanciful costumes. His main aim is to show the abeyance of class system and sexual boundaries as the masquerade is performed on the streets, It causes the authority's challenge to confront this phenomenon. Castle approaches the carnival as a confrontation between the authority and the common people; nonetheless, such perspective can turn around other issues like feminism in which the confrontation is caused by gender discrimination. As Clare Lewis and Steve Pile in their article entitled "Woman, Body, Space: Rio Carnival and the Politics of Performance" explore a new perspective in the Brazilian carnival regarding feministic aspects. The article shows the Brazilian carnival that contains some cultural values which are unsettled with the authority and a new prospect is opened to the feminism to show new possible interpretations when it is rendered indeterminate and unknowable.

Closer reading of carnival regarding gender studies has revealed more nuanced studies pertaining to this issue. Peter Tokofsky in his essay "Masking Gender: A German Carnival Custom in Its Social Context" studies carnival performance at a different angle. He first refers to the variety of costumes, customs, displays and dramas found in Carnival celebrations. Furthermore, he mentions that such celebrative ceremonies are shorn of a great variety of themes. However, one essential theme which revolves around the whole ceremony is called the reversal phenomenon. The reversal theme is at work in status, age, wealth and most prominently gender. Tokofsky focuses his attention on the social role of gender and how its subversive power leads to the changing of social norms. Other studies have constructed new beliefs from carnivals and have imparted the formation of new identities. Keith Nurse in his article "Globalization and Trinidad Carnival: Diaspora, Hybridity and Identity in Global Culture", investigates the nature of Trinidad carnivals which are known as the source of inspiration for carnivals 
throughout the world. He presents it more like a hybrid space which has dissolved multiple ethnicities and cultures under the title of colonial and capitalist expansion. As such, he believes that identities are always in the process of formation. On the other hand he refers to the occurrence of Caribbean carnivals in other places of diasporic communities which is referred to as 'globalization in reverse' by Nurse.

All these studies have carved out new ideologies from the physical act of carnival. However, none of these studies have been comprehensive enough to show a panorama view of carnival in comparison with what Michael Bakhtin has done in his towering work entitled Rabelais and His World. Bakhtin's work has a common point of comparison with the above mentioned studies. All these studies have used the same strategy that Bakhtin has expounded in his book which is the subversion of the established norms and the institutions of the society. Yet Bakhtin's general tenor is leaned toward the study of literature and language. Indeed, his notion of carnival encompasses a dynamic view as opposed to the absolute and established truth of the time. Bakhtin's first translator into American academy, Caryl Emerson has noted that "the weakest, least consistent, and most dangerous category in Bakhtin's arsenal is the concept of 'carnival"' $(1988,520)$. Such view can be attributed to the harsh regime of Stalin who would instantly ban any work of art deviated away from the established laws and regulations. This is why Bakhtin's Rabelais and His World was not studied until 1947 (Dentith, 1995, 63).

Bakhtin develops a theory of carnival to stem the restrictions that sap at the roots of human's action and thought. Having sketched out the Carnivalesque theory, he evolves out of it to "articulate an aesthetic which celebrates the anarchic, bodybased and grotesque elements of popular culture, and seeks to mobilize them against the humorless seriousness of official culture" (64). As such, he alerts us to the fact that the Carnivalesque spirit is more important than the carnival itself and cast its net more wildly to encompass diverse subversive elements under the rubric of grotesque realism. For Bakhtin, "the aesthetic focus of grotesque realism is of course the grotesque body" (79). With Bakhtin's critical eye, body imagery underline the necessity for a new interpretation which is distanced from the ordinary notion proportioned to it. The new interpretation purveys to the reader those images "predominate in the extra-official life of the people. For example, the theme of mockery and abuse is almost entirely bodily and grotesque" (228). Bakhtin never adumbrate the concept of grotesque realism whereas orchestrates all the varying points and braids them together so far to be capitalized on the concept of grotesque realism. 


\subsection{Theoretical Framework}

Realism is defined simply as "representing human life and experience in literature" (Abrams \& Harpham, 2004, 303). This means that a wide range of experiences are imparted to the concept of realism which is to be encapsulated in literature. The author whosoever writes in this mode consists with the view that "realism represents life and the social world as it is to the common reader" (ibid). This implied notion is the reactionary force against presenting life as it is to the common people by the government or any other external force. In such case, presenting the life as it is can become an arduous task for the author. Nonetheless, an intellectual writer tries to find his/her ways out of such a difficult situation. In this respect, Bakhtin explicitly expounds on a special style of writing used by different authors to present life as it is. Hélène Iswolsky, who introduced Bakhtin to English readers by translating Rabelais and His World, asserts that Bakhtin has taken upon himself "to interpret the world for his society" (1984, xiv). Moreover, it should be mentioned that at the time of writing his book, Bakhtin was living in a communist society which was opposed to bear any new interpretation of the world other than the one prescribed by their committee.

Bakhtin never tried to follow the well-trodden path of socialist realism of the communist party instead he adopted a different perspective upon the world as opposed to the common one because "during 1932 all authors, no matter what their styles or politics, were forced to join the new Union of Writers" (xvii). Bakhtin, opposed the unification of all styles and aesthetics, and supported a "celebration of linguistic and stylistic variety as counter to tight canonical formulas for the novel (and for other genres and even media, such as films or painting) proposed by official spokesmen for the Soviet government"(ibid). Instead of focusing on the formal communication among the people, Bakhtin deeply probed those aspects of life that were not examined due to their levity. This was probably his cogent reason of citing François Rabelais (1494-1553), the author of The Life of Gargantua and of Pantagruel, as one of the greatest writer of all times. Indeed, his entire attempt was directed toward the creation of a new literary form named "grotesque realism" to view the world differently.

In Rabelais and His World, Bakhtin draws his attention to Rabelais's Gargantua and Pantagruel to acknowledge his new ideas. Bakhtin's consideration of Rabelais is thoughtful in its priority given to Rabelais: "Of all great writers of world literature, Rabelais is the least popular, the least understood and appreciated. And yet, of all the great creators of European literature Rabelais occupies one of the first places" (1). His rational justification in giving such a high priority to Rabelais lays in his attempt to revive the thousand years of folk culture: "His [Rabelais] 
work, correctly understood, casts a retrospective light on this thousand-year-old development of the folk culture of humor, which has found in his works its greatest literary expression" (4).

Indeed, he adds that the folk culture of humor was cardinally important to the Middle Ages and the Renaissance period because a strong resistance was offered by the expression of the folk culture to "oppose the official and serious tone of medieval ecclesiastical and feudal culture"(ibid). This was exactly what Bakhtin needed to build upon his concept of "grotesque realism". Drawing further attention to a common point of comparison between Bakhtin and Rabelais, Iswolsky mentions:

Each created a special kind of open text that they explored as a means for inscribing themselves into their times. Both Rabelais and Bakhtin knew that they were living in an unusual period, a time when virtually everything taken for granted in less troubled ages lost its certainty, was plunged into contest and flux (xv).

In other word, both Bakhtin and Rabelais felt a compelling need of selecting a new base for a period which has lost all its certainty. As such, Bakhtin decides to build his theoretical work upon Rabelais's revolutionary perspective toward the world which has the same potential force to change the ordinary way of approaching the world. However, his interpretation of Rabelais has a unique perspective:

Rabelais' basic goal was to destroy the official picture of events. He strove to take a new look at them, to interpret the tragedy or comedy they represented from the point of view of the laughing chorus of the marketplace. He summoned all the resources of sober popular imagery in order to break up official lies and the narrow seriousness dictated by the ruling classes. Rabelais did not implicitly believe in what his time 'said and imagined about itself'; he strove to disclose its true meaning for the people, the people who grow and are immortal (439).

Bakhtin glorifies Rabelais's daring method of dealing with the world. $\mathrm{He}$ establishes Rabelais's exploration of folk culture as his pillar of opinion and categorizes the folk culture presented in The Life of Gargantua and of Pantagruel into three groups as follow: "1. Ritual spectacles: carnival pageants, comic shows of the marketplace. 2. Comic verbal compositions: parodies both oral and written, in Latin and in the vernacular. 3. Various genres of billingsgate: curses, oaths, popular blazons" (5). These are three main factors that contribute to the establishment of a new perspective in which people can communicate within its structure and choose the way of living in a new world which could "offer a 
completely different, nonofficial, extra ecclesiastical and extra political aspect of the world, of man, and of human relations" (6). However, Bakhtin also notices Rabelais's exaggerated consideration of the human body with an unexpected direction toward its specific part of human body:

It is usually pointed out that in Rabelais' work the material bodily principle, that is, images of the human body with its food, drink, defecation, and sexual life, plays a predominant role. Images of the body are offered, moreover, in an extremely exaggerated form. (18)

Different exaggerated images of the body have been abundantly mentioned in Rabelais's work and Bakhtin has been vigilant enough to take them into his consideration of the grotesque realism. Bakhtin mentions that Rabelais has taken into account those parts of the body which are open to the world and thus, "the acts of the bodily drama, take place"(317) in those parts. These acts are "eating, drinking, defecation and other elimination (sweating, blowing of the nose, sneezing), as well as copulation, pregnancy, dismemberment, swallowing"(317) because "these acts are performed on the confines of the body and the outer world"(ibid). For Bakhtin, interconnections between the body and the outer world play a predominant role due to the place of the body on the threshold of changing and becoming a new body which may lead eventually to "the feast of becoming, change, and renewal" (10). Likewise, Bakhtin aimed at achieving a renewal of Russian's thoughts deeply soaked up in the concept of Socialist Realism. Eventually, all his attempts led to the creation of a new literary mode called grotesque realism with specific features which can be used to shatter the routine perspectives of investigating different cultures. 2.3 Sadegh Chubak's Life and Style:

Chubak was born in Bushehrin 1916 and grew up in Shiraz where the settings of most of his stories are take place. However, taking his diploma from an American College in Tehran and acquiring English language, he gained access to the English short stories which then helped him make his path of a professional writer. $\mathrm{He}$ never had to wait for the greater part of his life to be wildly recognized by others as" during the First Congress of Iranian Writers ${ }^{1}$, Parviz Natel Khanlari, an Iranian literary scholar, introduced him who was then a young writer of late twenties as having a promising future in short story writing (Moshtagh Mehr, 2011, 3). By that time, he had found himself writing in a naturalistic style which caused him to be a well-recognized short story writer. His first collection of short stories entitled "The Puppet Show"(Kheyma-sab-bazi, 1945) brought him instant fame (Ghanoonparvar,

${ }^{I}$ The First Congress of Iranian Writers is the most important literary and cultural event during the last two hundred yearswhich was held in July 1946. 
2009). After that he published four collections of short stories and two novels until 1966. He left Iran before the Islamic Revolution and never came back while finally he died in a state of self-exiled in California in 1988.

2.4 Bakhtin's Theory of Grotesque Realism in Chubak's "An Afternoon in Late Autumn"

The story "An Afternoon in Late Autumn" (Ba'dazZohr-e Akhar-e Pa'iz) that we are studying at hand is included in Chubak's first collection of short story written in November 1945. The story narrates one day life of a boy named Asghar studying in an elementary school. He cannot concentrate on his lessons in the class and confronts the teacher's harsh rebuke who teaches Islamic rituals. As the story goes on, Asghar's stream of consciousness about the past events is simultaneously coincided with the teacher's task of teaching the Islamic ritual. Indeed, Chubak juxtaposes these two events togrue somely describe Ashagr's situation that might have survived under more favorable circumstances but is doomed to failure under the present situations that press him the forceful implementation of Shi'i practices.

Chubak wrote this short story in one of the most turbulent time of Iran's history. It was written during the time when a heated political conflict was emerged between Mohammad Reza Shah (1919-1980) and his democratically elected prime minister, Mohammad Mosaddegh (1882-1967). The conflict was finally settled down by over throwing Mosaddegh through a coup d'état. This incident led to an approximate disregard of Iranian culture which was on the verge of modernization. As such, Iranian writers considered themselves as the "Iranian intelligentsia and a voice of morality for the Iranian future" (Hillmann, 1982, 6). To this end, their central issue raised in relation to the beginning of modernization in a religious based society like Iran. Thereupon, the majority of Iranian modernist writers advocated modernism as opposed to the deep-rooted Shi'ism and developed "a pervasive anti-Shi'i animus in imaginative literary works at the very least of anticlericalism and the rejection of many folk-Shi'i practices (7). Anyway, many of Iranian intellectuals deduced that "the Iranian people's multifaceted backwardness, much of it is attributed to the influence of Shi'ism in daily life" (8). Although there were some writers like Jalal Al-e-Ahmad (1923-1969) who tried to reform the folkShi'i practices to reach a consensus with modernism, some extremist writers like Chubak rejected religion practices of any kind (12).

Chubak's radical view toward the Islamic practices is clearly expressed in "An Afternoon in Late Autumn". In fact, as he explores one of the most important Islamic practices in the most gruesome way. Bakhtin's categorization of folk culture was based on the parodic presentation of a ritual spectacle so as to shock 
and disturb the routine method of dealing with rituals by providing a new perspective. He emphasizes on the prescription of a true picture of the world even if it is a gruesome picture. In this regard, Chubak describes a teacher who teaches a ritual Shi'i practice as a highly valued subject with some awkward, offensive and blasphemous details. For example, Chubak describes the students of the class in this way

The composition of their faces was somehow incomplete. The artistry of their creator was still required to bring them to completion, to make them resemble the faces of their fathers. Certainly if an accomplished sculptor had composed these visages, he would have never allowed anyone to take them out of his studio and put them on public show, because, all other considerations aside, they would reveal his lack of skill and ruin his reputation (Chubak, 2007, 70).

This awkward description of the students is followed by the teacher instructing Qonut (part of Muslim's praying) as he says:

In the second rak'at, or unit of prayer, after recitation of the Hamdu Surah [praises be to God], we extend our arms before us, palms upward, and recite the following: 'Our Lord, bestow upon us benefaction in this life and benefaction in the hereafter. This is called qonut, or submission (ibid).

By such juxtaposition, Chubak associates the high subject of instructing Qonut with such an offensive description of the students to firmly attack the deep-rooted of religious percepts. Bakhtin believes that "the essential principle of grotesque realism is degradation, that is, the lowering of all that is high, spiritual, ideal, abstract; it is a transfer to the material level, to the sphere of earth and body in their indissoluble unity $(1984,20) "$. Therefore, Chubak uses a metaphor in his description of the students by asserting a comparative ground between God and the sculptor. Certainly, he never aims to blame God for creating such ugly students instead he blames God for creating such miserable situation for the students. Moreover, he places his description of the students before the teacher instructing Qonut to reveal a significant point regarding its meaning. Qonut means submission to the will of God and Muslim splead God in their praying for benefaction. Chubak is harshly criticizing the students' miserable life while they are only allowed to submit to their God's will and plead for His benefaction which may not be granted to them. The Muslim blind imitation of religious practices without caring about its content is Chubak's another rtarget for condemnation. Bakhtin believes that a ritual subject should become denigrated so as to become "blessing and humiliating at the same time (151)". Indeed, Chubak's presentation of the ritual incident forms such 
situation. Though the Shi'i practice is itself consecrating, it is used to shockingly present those parts of banal realistic life that are usually ignored.

Following Bakhtin's categorization of folk culture, we investigate the form of language used in such situations. Bakhtin gives a high priority to the usage of abusive language because in his view this type of language has the power to make a connection with the low level of grotesque literature:

The importance of abusive language is essential to the understanding of the literature of the grotesque. Abuse exercises a direct influence on the language and the images of this literature and is closely related to all other forms of "degradation" and "down to earth" in grotesque. $(1984,27)$

Chubak reveals a strong tendency to use colloquial abusive language in his writings, even though ,it may provoke some critics' uncomplimentary remarks. As such, Elwell Sutton (1971) in "The Influence of Folk-tale and Legend on Modern Persian Literature" that Chubak"is at great pains to reproduce ... speech, to a degree of realism that many readers have found offensive" (250). Indeed, Chubak's writing can be categorized through use of abusive language. In the same retrospect, he recruits abusive language in several places in "An Afternoon in Late Autumn". Within the story, it is often used when the teacher begins talking to Asghar Sopuriyan whose attention has been distracted from the class:

Aha, Sopuriyan, stupid little calf! Aha, little spawn of a bitch! And just where were you drifting to just now? I'm saying all of this for your benefit, so that tomorrow, when there's a test, you won't stick in the mud like a lame ass! Dust and ashes of shame and disgrace upon the head of the stinking little worm, little broken-necked fool! (Chubak, 2007, 72)

The more a language is filled with formality, the more it keeps a distance among those communicating within the language. In a like manner, a story can follow the same rule when it is expressed in formal language though it keeps a distance between the reader and the story. When the story is expressed in abusive language, it helps the reader cut sharply through the story into the action and involve with it instantly. In the same respect, Chubak includes the same feature in his story by using abusive language. He shocks the reader by minimizing the distance between the reader and the miserable character. In fact, the ugliness of the abusive language is used for shocking the reader into taking a different perspective toward the character. Therefore, he affords the abusive language with great significance to startle the reader into noticing the horrible situation of the dejected character. 
Direct representation of the human body is of high importance in grotesque realism. In the same line, Chuabak has employed it masterfully in his "An Afternoon in Late Autumn". Generally, Bakhtin has attached significance to those parts of the body which are "open to the outside world, that is, the parts through which the world enters the body or emerges from it, or through which the body itself goes out to meet the world" (Bakhtin, 1984, 26). As such, in exploring the traces of grotesque realism in a work of literature, one can direct his attention to those parts of the body which are open to the world since "the confines between bodies and between the body and the world are overcome: there is an interchange and an inter orientation"(317). In the same respect, Chubak aptly employs those parts of the body which are open to the world in his story. In one part of the story, Asghar delving into his past memories remembers himself with another person named Mash Rasul who has sodomized him by giving some food and money to him: "He kisses me-he touches me nice and soft-and-and then...but after in the evening when we come back to the city together in a smoking machine Mash Rasul gives me five rials" (Chubak, 2007, 75). Again, Chubak describes this act of sodomization by juxtaposing it with some parts of the religious practice taught by the teacher. This occurs when Asghar is trying to distinguish between raku' and sojud (parts of Muslim praying). The difference between these paces lies in the way that raku' refers to the time when a Muslim bends over and sojud refers to the time when the Muslim gets on the ground and pronounce their prayers. At his juncture, Asghar who is trying to learn the difference between these two, remembers his time with Mash Rasul:

He imagined that one of them was raku' and one sojud. But the images faded from his mind and he thought, "That one raku' is when they get down and put their heads on the prayer stone, and they bend over"-and again he thought of Mash Rasul and shame arose in him and he blushed to the ears-"(77)

Closer reading of Chubak's writing can reveal that his naked representations of those parts of the body open to the world are not only exposed by referring to the sexual acts but also he examines some other parts of the body open to the world like nose. Nose is one part of the body which has great importance in grotesque realism. As Bakhtin mentions: "we are interested in the theme of the nose itself, which occurs throughout world literature in nearly every language, as well as in abusive and degrading gesticulations (1984316)".An example in the story shows that the teacher blows out his nose and takes a contemplative look at it. "The teacher held his handkerchief, crumpled and dirty. He opened it and blew his nose into it with a large blast, then looked intently into it at the deposit he had left 
(Chubak, 2007, 79). Also, in another part of the story, Asghar is described in taking out a ball of snot from his nose:

Then he stuck his finger in his nose and picked at it and took out a little ball of dried snot, which had been stuck to the inside wall of his nose, with his fingernail, and he stuck his hand under his desk and rolled it around between his fingers. But suddenly it slipped out of his fingers and fell on the floor, and he was sad. (76)

Such awkward descriptions abound in Chubak's stories. In fact, he weaves his subject with such description to shock the reader and compels him/her to change his/her perspective toward the world. For Chubak grotesque imagery is accepted to be a method of including all aspects of life, of studying the relation between the highest and the lowest aspects of reality so as to prepare the reader to seriously contemplate the world. Such juxtaposition brings with itself oppositional episodes of both resisting the dominant ideology and at the same time reproducing a more acceptable perspective to the society. Expectantly, Chubak ends the story by pictorializing another shocking picture. When Asghar grows utterly dejected in the class, he veers off his view from the class to the outside through the window in the class. He notices a man in a large neighboring garden who holds a knife for cutting the heads of the chickens off. The man is not successful in cutting the chicken's neck instantly because his knife is not sharp enough. Then, instead of sharpening the knife, the man plucks the feathers of their neck off and cut their necks one after the other. This scene attracts Asghar's attention considerably: "Asghar was still absorbed in watching the jumping and jerking of the dead chickens when he again sensed that the class had grown still" (Chubak, 2007, 79). By pictorializing a horrible act of killing animals, Chubak is referring to the miserable life of Asghar which is destined to end tragically like those cut-headed chickens. It ends in a situation to which cruel God will not even bother himself to sharpen the knife, instead plucks off the feathers, a meaningful comparison to highlight the extent of Asghar's horrible situation.

Chubak's grotesque realism changes our world into an unpleasant one deprived of any possible hope for survival. His character's attempt fails to reach any success as he is bound in an indifferent and inimical society. He is only moved forward with an instinctive urge through an uncertain society. Accordingly, Barahani has mentioned regarding Chubak's character that "their life is as black as the night" (p. 670). Therefore, with such evidences grotesque realism suits best to portray the people's terrible situation in attracting instantly every body's attention. Thus, its concept is not restricted to a simple action whereas it is bound up with the effect of an action: 
The grotesque is best understood by what it does, not what it is. It is an action, not a thing - more like a verb than a noun. [...] Grotesques come into being by rupturing cultural boundaries, compromising and contradicting what is "known" or what is "proper" or "normal". (Connelly, 2012, 2)

\section{Conclusion}

Modernism began abruptly in Iran which was deeply rooted in Islamic thoughts. The clash of these two issues, modernism and religious beliefs led to the formation of class distinctions. As a naturalist writer, Chubak tries to portray the miserable life of the poor struggling for their existence. His stories are experiences of the human nature that is bearing different stages which portrays his style of cutting through the filthy life of the poor and describing their ugliness so as to shock his reader. Through Bakhtin's theory of grotesque realism, one can explore Chubak's style of writing and investigate the intricacies of his writing that sound quite appalling at first but can shock the reader and help him/her to achieve a new level of moral standard particularly in respect to the struggle of poor people for survival. The story, "An Afternoon in Late Autumn" is mostly narrated from an underprivileged boy's stream of consciousness that is cruelly traumatized by a society quite indifferent to him. Seemingly, Chubak focuses his camera on one day of his subject and presents it to us by including all the gruesome details. His descriptions mostly include the portrayal of grotesque body which can carry the "the theme of the change of epochs and the renewal of culture" (Dentith, 1995, 232). Consequently, his presentation appalls his reader as it offers new ways of experiencing the traditions and religious concepts. Indeed, it is in such a critical moment which grotesque realism can suit best and startle the reader's mind behind his/her expectation to seriously contemplate the world.

\section{References and notes:}

Abrams, M. H. Harpham G. (2004), Glossary of Literary Terms (9th ed.). United States: Earl McPee.

Aliakbari, R. (2015). Death in the Prism of Existentialism: A Comparative Reading of William Faulkner's As I Lay Dying and Sadeq Chubak's The Patient Stone, Persian Literary Studies Journal, 4(5-6), 1-21.

Bakhtin, M. (1984) Rabelais and His World, Translated by Helene Iswolsy, Bloomington: Indiana University Press. 
Sayed Mohammad Anoosheh, Muhammad Hussein Oroskhan,

Baraheni, R. (1969) Qeșsanevisi (Story Writing), Tehran: Negah Publication, 1969, 548713.

Chubak S., Bryant C., (2007) An afternoon in late autumn: a story, Iranian Studies, 15(14), 69-79.

Castle, T. (1986). Masquerade and civilization, The carnivalesque in eighteenth Century English culture and fiction. California: Stanford University Press.

Connelly, F. S., (2012) The Grotesque in Western Art and Culture: The Image at Play, Cambridge: Cambridge University Press, p. 2.

Dabashi, H.(2001).Close Up: Iranian Cinema, Past, Present, and Future. London: Verso.

Dabashi, H. (2012). The World of Persian Literary Humanism, London: Harvard University Press.

Dentith, S. (1995), Bakhtinian Thought: An Introductory Reader. London: Routledge.

Elwell-Sutton L. P. (1971) "The Influence of Folk-tale and Legend on Modern Persian Literature," in Iran and Islam, C. E. Bosworth, ed., Edinburgh, Edinburgh University Press.250-251.

Emerson, C. (1988), "Problems with Baxtin's Poetics", Slavic and East European Journal, 32, , 503-25, p. 520.

Ghanoonparvar, M. R. (2009). Sadegh Chubak, Retrieved from http://www.iranicaonline.org/articles/chubak-sadeq.

Gniadek, M. (2005) The Art of Becoming: Sherwood Anderson, Frank Sargeson and the Grotesque Aesthetic, Journal of New Zealand Literature, 23(2), 21-35.

Hillmann, Michael C. (1982) The Modernist Trend in Persian Literature and Its Social Impact, Iranian Studies, 15 (1/4), 7-29.

Lewis, C., and Pile, S. (1996). "Woman, body, space: Rio carnival and the politics of performance", Gender, Place and Culture, 3(1), 23-41.

MoshtaghMehr, R. (2011), "A Study of the Form and Structure of Sādegh Chuback's Short Stories", Contemporary Persian Literature, 1(1), 117-131.

Mostaghel, D. M. (1979) The Second Sadeq: The Short Stories of Iranian Writer SadeqChubak, World Literature Today, 53(2), 227-231.

Nurse, K., (2010), "Globalization and Trinidad carnival: Diaspora, hybridity and identity in global culture", Cultural Studies, 13(4), 661-690.

Oroskhan, M. H.,Zohdi E. (2016) NimaYushij's "Afsaneh" as a Striking Exemplar of the 'Greater Romantic Lyric', International Letters of Social and Humanistic Sciences, Vol. 66, 23-30.

Sadr, H. R. (2006). Iranian Cinema: A Political History. London: I.B.Tauris\& Co. Ltd.

Tokofsky, P. (1999), "Making gender: A German carnival custom in its social context", Western Folklore, 8(3/4), 299-318.

Turdiyeva, O. (2016). Modern Iranian Literature: The Historical and Present Development of the Short Story Genre, Journal of Literature and Art Studies, 6(7), 775-784. 


\title{
Summary
}

\section{Condemnation of Religious Concepts: An Examination of Chubak's "An Afternoon in Late Autumn" through Bakhtin's Theory of Grotesque Realism}

\author{
Sayed Mohammad Anoosheh \\ Yazd University, Yazd, Iran \\ Muhammad Hussein Oroskhan \\ Shiraz University, Fars, Iran
}

The first traces of modernism in Iranian society can be found in the second decade of twentieth century which was deeply embedded with religious concepts. With regard to Persian literature, short story was developed as a new genre and a sign of modernism of that period by prominent Iranian writers such as Sadeq Hedayat (1903-1951), Mohammad Ali Jamalzadeh (1892-1997) and Sadegh Chubak (1916-1998). In this way a cultural clash was broken out between the traditional religious concepts and the new modern ideas. Among these writers, Chubak was more influenced by the doctrine of modernism. He expressed his message colloquially through his short stories to instigate the lower part of society. His naturalistic style of writing delved into the most gruesome details of people's life with the aim of shocking his reader in experiencing a new perspective previously ignored. To highlight Chubak's style of writing attempt is made to explore one of the highly praised short stories entitled "An Afternoon in Late Autumn" on the ground of the Bakhtin's theory of grotesque realism cited in Rabelais and His World. Grotesque realism is a site upon which religious and social hierarchies can be subverted and renewed. This study tries to reveal that Chubak followed the Bakhtin's grotesque realism to evoke a new outlook particularly in the lower section of society.

Key Words: Chubak, Modernism, Bakhtin, Grotesque realism, Religion. 